Meltem: izmir Akdeniz Akademisi Kitabı (Aralık 2016): 129, DOI 10.32325/iaad.2016.11

(c) Izmir Akdeniz Akademisi

\title{
Manisa Akhisar Oteli, 2008/2016
}

\section{Çağrı Gürbüz}

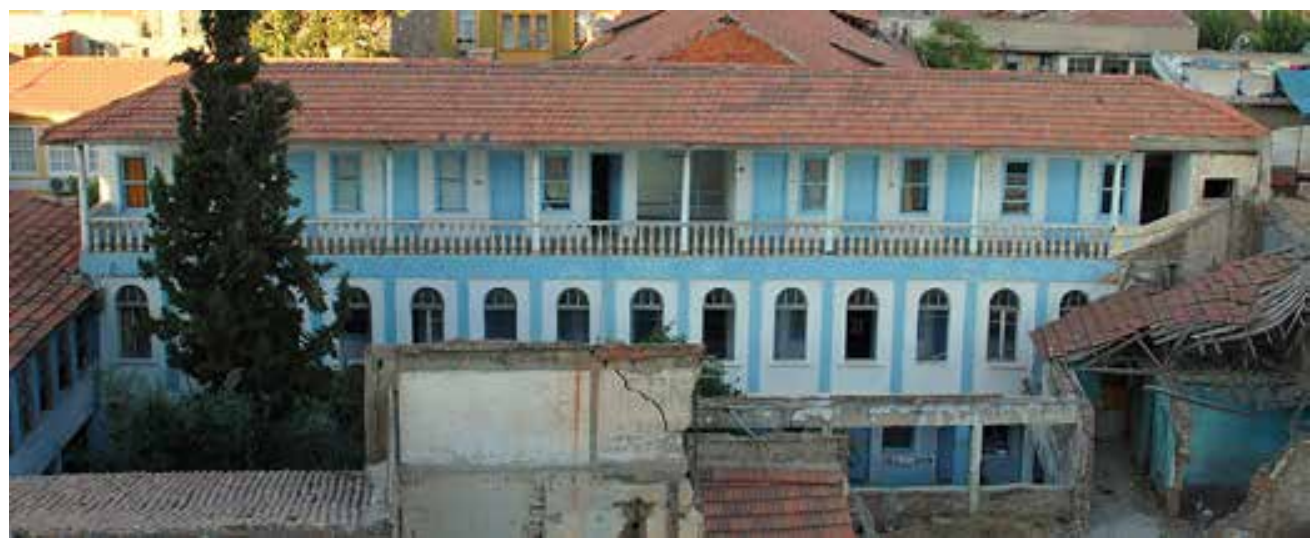

Manisa Akhisar Oteli, 2008

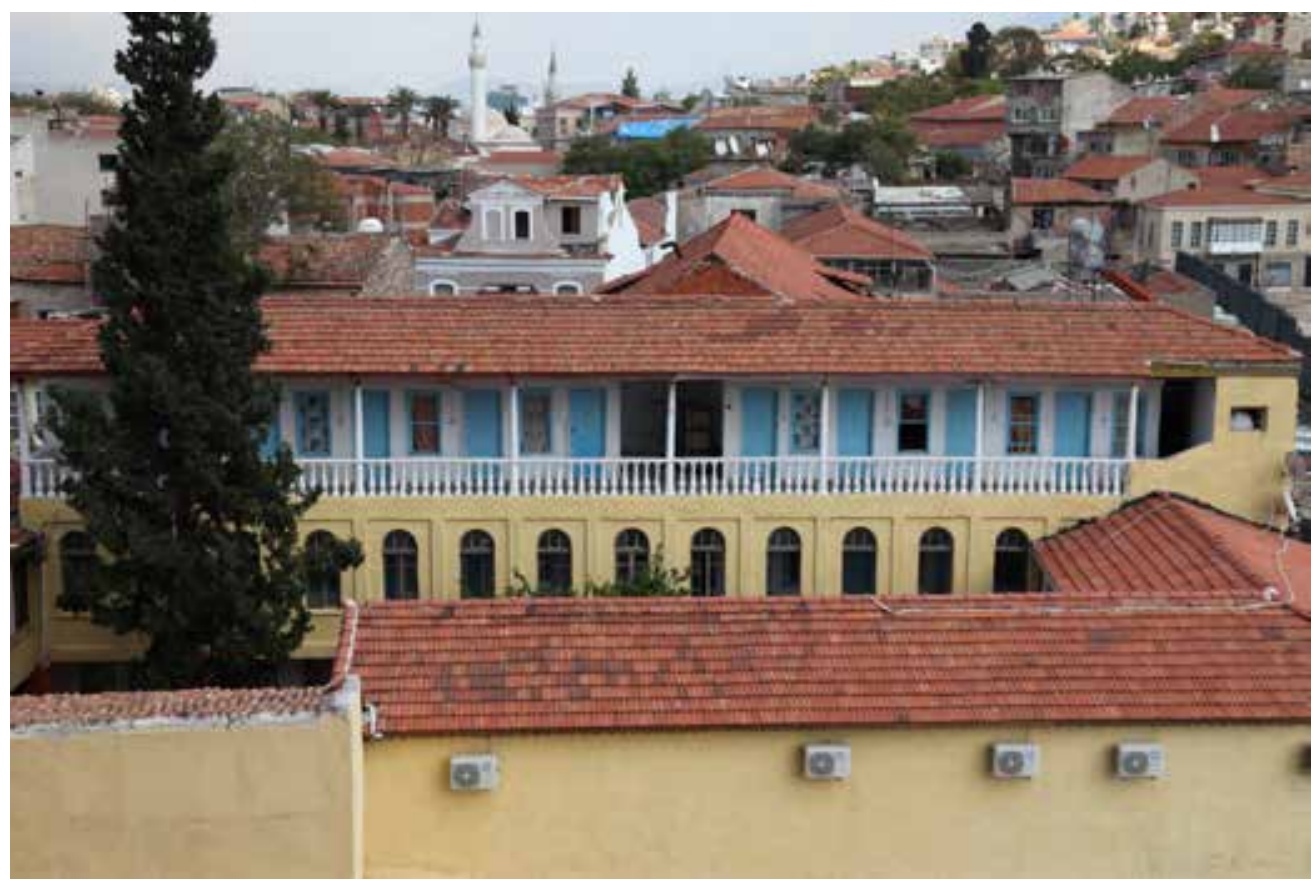

Manisa Akhisar Oteli, 2016 